\title{
Bioluminescence in the Deep-Sea Cirrate Octopod Stauroteuthis syrtensis Verrill (Mollusca: Cephalopoda)
}

\author{
SÖNKE JOHNSEN ${ }^{1}$, ELIZABETH J. BALSER ${ }^{2}$, ERIN C. FISHER ${ }^{1}$, AND EDITH A. WIDDER ${ }^{1}$ \\ ${ }^{1}$ Marine Science Division, Harbor Branch Oceanographic Institution, Ft. Pierce, Florida; and \\ ${ }^{2}$ Department of Biology, Illinois Wesleyan University, Bloomington, Illinois
}

\begin{abstract}
The emission of blue-green bioluminescence $\left(\lambda_{\max }=470 \mathrm{~nm}\right)$ was observed from sucker-like structures arranged along the length of the arms of the cirrate octopod Stauroteuthis syrtensis. Individual photophores either glowed dimly and continuously or flashed on and off more brightly with a period of 1-2 seconds. Examination of the anatomy and ultrastructure of the photophores confirmed that they are modified suckers. During handling, the photophores were unable to attach to surfaces, suggesting that, unlike typical octopod suckers, they have no adhesive function. The oral position of the photophores and the wavelength of peak emission, coupled with the animals' primary postures, suggests that bioluminescence in S. syrtensis may function as a light lure to attract prey.
\end{abstract}

\section{Introduction}

Bioluminescence is a common and complex characteristic in coleoid cephalopods. A large percentage of these animals are bioluminescent, many possessing complicated light organs utilizing lenses, reflectors, irises, interference filters, pigment screens, and shutters (Harvey, 1952; Herring, 1988). The diversity of the morphologies and anatomical distributions of cephalopod photophores is unparalleled among invertebrate phyla (Voss, 1967; Herring, 1988). However, despite this extraordinary radiation, bioluminescence appears to be rare among octopods. Although 63 of the 100 genera of squid and cuttlefish have bioluminescent species, only 2 of the 43 genera of octopods have species confirmed to be bioluminescent- the bolitaenids Japetella and Eledonella (Robison and Young, 1981; Herring et al.,

Received 16 March 1999; accepted 27 May 1999

Address for correspondence: Dr. Sönke Johnsen, MS \#33, Woods Hole Oceanographic Institution, Woods Hole, MA 02543-1049. E-mail: sjohnsen@whoi.edu
1987; Herring, 1988). In these genera, the light organs are found only in breeding females (Robison and Young, 1981) and are restricted to tissues associated with the oral ring and the base of the arms (Herring et al., 1987). In the case of cirrate octopods, bioluminescence has been suggested but never confirmed (Aldred et al., 1982, 1984; Vecchione, 1987).

This study provides the first description of bioluminescence in the cirrate octopod Stauroteuthis syrtensis. We also describe the anatomy and ultrastructure of the photophores in comparison with the morphology reported for cephalopod photophores (Herring et al., 1987) and octopod suckers (Kier and Smith, 1990; Budelmann et al., 1997). In addition, we present a hypothesis to explain how the presence of light organs relates to the feeding behavior postulated for these animals. A preliminary account of this research has been presented by Johnsen et al. (1999).

\section{Materials and Methods}

\section{Source and maintenance of animals}

Three specimens of Stauroteuthis syrtensis were obtained during a cruise of the R.V. Edwin Link to Oceanographer Canyon (on the southern rim of Georges Bank, USA) in August and September 1997. The animals were collected at depth using the research submersible Johnson-Sea-Link outfitted with acrylic collection cylinders (11-liter volume) with hydraulically activated, sliding lids. The three specimens were caught during daylight at depths of $755 \mathrm{~m} \mathrm{(225}$ $\mathrm{m}$ from bottom), $734 \mathrm{~m}$ ( $246 \mathrm{~m}$ from bottom), and $919 \mathrm{~m}$ (165 $\mathrm{m}$ from bottom) (dive numbers 2925 and 2927) and maintained for up to 2 days at $8^{\circ} \mathrm{C}$ in water collected at depth. 


\section{Video and photography}

Specimens were videotaped in two situations. First, the behavior of two animals was recorded from the submersible. Second, the captured animals were filmed aboard ship in the dark by using an intensified video camera (Intevac's NiteMate 1305/1306 CCTV intensifier coupled to a Panasonic Charge Coupled Device). During shipboard filming, the animals were gently prodded to induce bioluminescence Representative video frames were digitized (ITSCE capture board, Eyeview Software, Coreco Inc.). The animals were also placed in a plankton kreisel (Hamner, 1990) and photographed with a Nikon SLR camera with Kodak Elite 100 color film. Data from a previously recorded in situ video of a specimen of $S$. syrtensis from the slope waters near Cape Hatteras at $840 \mathrm{~m}$ (35 m from bottom; August 1996; R.V. Edwin Link; dive 2777) are also reported in this paper.

\section{Spectrophotometry}

Bioluminescent spectra were measured using an intensified optical multichannel analyzer (OMA-detector model 1420, detector interface model 1461, EG\&G Princeton Applied Research) coupled to a 2-mm-diameter fiber optic cable. The detector was wavelength calibrated using a lowpressure mercury spectrum lamp (Model 6047, Oriel Inc.) and intensity calibrated using a NIST referenced low-intensity source (Model 310, Optronics Laboratories) intended for the calibration of detectors from $350 \mathrm{~nm}$ to $800 \mathrm{~nm}$. For further details on the theory of operation and calibration of the OMA detector, see Widder et al. (1983). Three emission spectra were recorded from one animal, and an average spectrum was calculated.

\section{Microscopy of photophores}

The fixation, dehydration, and infiltration procedures were performed at room temperature aboard the R. V. Edwin Link. The animals were sacrificed by over-anesthesia with MS222 (Sigma Chemicals Inc.). One specimen was fixed in $10 \%$ formalin in seawater and dissected to confirm species identification. One arm of a different specimen was fixed in $2.5 \%$ glutaraldehyde in $0.2 \mathrm{M}$ Millonig's buffer at

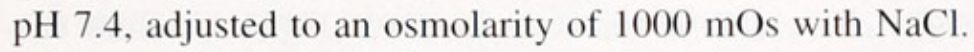
After an initial 1-h fixation, several photophores were dissected from the arm and placed in fresh fixative for an additional $5.5 \mathrm{~h}$. Postfixation of the dissected photophores in $1 \%$ osmium tetroxide in Millonig's buffer for $70 \mathrm{~min}$ was followed by dehydration through a graded series of ethyl alcohols. Over a period of 6 days, the specimens were slowly infiltrated with propylene oxide and Polybed 812 (Polysciences) and then embedded in Polybed 812.

Semithin $(1 \mu \mathrm{m})$ and thin sections of embedded material were cut with a diamond knife (Diatome) and a Sorvall MT2 rotary ultramicrotome. Semithin sections were stained with $2 \%$ toluidine blue in $1 \%$ sodium borate and photographed with a Zeiss Photomicroscope II using Kodak Tmax 100 black-and-white film. Intact arms fixed in 10\% formalin in seawater were photographed with a Tessovar photographic system. Thin sections for ultrastructural evaluation were stained with aqueous $3 \%$ uranyl acetate and $0.3 \%$ lead citrate. Stained sections were viewed and photographed with a Zeiss EM 9 transmission electron microscope.

For scanning electron microscopy, an arm with suckers was fixed in $2.5 \%$ gluteraldehyde (as described above). dehydrated with ethyl alcohol, infiltrated with hexamethyldisalizane (Pellco), and air-dried. Micrographs were obtained with a JEOL JSM 5800LV scanning electron microscope using Kodak Polapan 400 film.

\section{Results}

\section{General description of animal and distribution of photophores}

Figures $1 \mathrm{~A}$ and $1 \mathrm{~B}$ show the largest of the three captured specimens of S. syrtensis. The appearance of the specimen is typical for the species (Vecchione and Young, 1997). The mantle length is about $9 \mathrm{~cm}$ (mantle lengths of other two specimens $\sim 6 \mathrm{~cm}$ ), suggesting that all three animals were immature (Collins, unpubl. data). The measurements are highly approximate because the mantle in the living animal is easily deformed. The primary webbing extends for about three-quarters of the length of the arms. The arms are oral to the primary web and attached to it by a secondary web. The photophores are arranged in a single row along the oral surface of each arm, situated between successive pairs of cirri (Fig. 1B). Each arm supports about 40 photophores. The distance between photophores decreases from the base to the tip of the arm, with the greatest distance being $4 \mathrm{~mm}$ and the smallest less than $0.1 \mathrm{~mm}$. The diameter and the degree of development of the photophores located at the tip are less than those located at the base of the arm. The fresh tissue of the entire animal had a gelatinous consistency typical of many deep-sea cephalopods (Voss, 1967). Although orange-red under the photo-floodlights, the color of the animal was closer to reddish-brown in daylight.

\section{Bioluminescence}

When mechanically stimulated, $S$. syrtensis emitted moderately bright, blue-green light $\left(\lambda_{\max }=470 \mathrm{~nm}\right)$ from the sucker-like photophores along the length of each arm (Fig. 2 ). With continuous stimulation, these photophores produced light for up to $5 \mathrm{~min}$, though the intensity of bioluminescence decreased over time. Individual photophores either glowed dimly and continuously or blinked on and off brightly at 0.5 to $1 \mathrm{~Hz}$. The blinking photophores cycled asynchronously, producing a twinkling effect. All suckers 

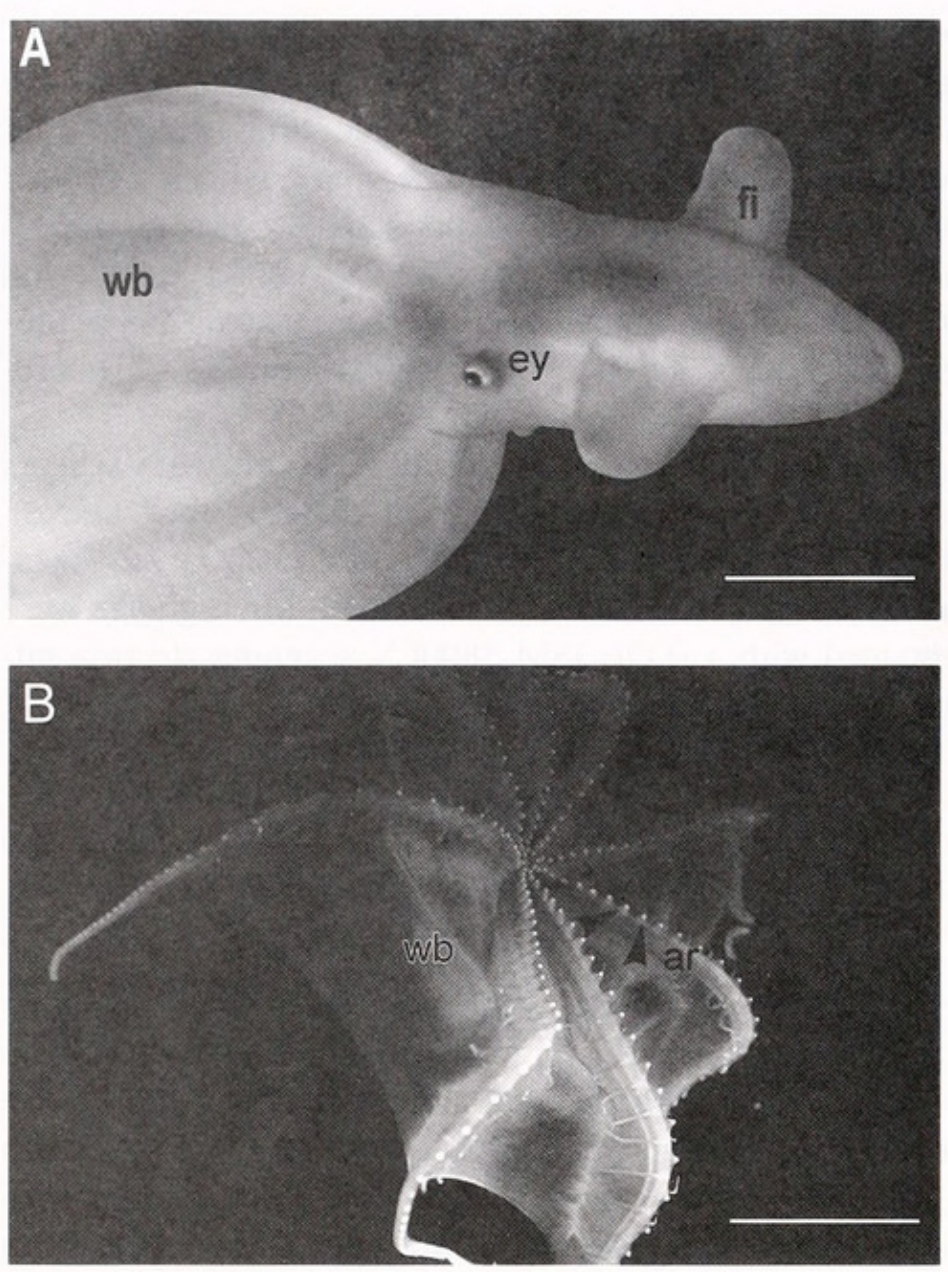

Figure 1. Photographs under artificial light of the deep-sea finned octopod Stauroteuthis syrtensis with the webbed arms in swimming posture (A) and spread (B) displaying the photophores/suckers (arrowheads) that appear as white spheres along the length of the inner surface of the arms. The posture shown in (B) may be one of extreme withdrawal intended to startle intruders with the sudden appearance of bioluminescent suckers. ar, arm; ey, eye; fi, fin; wb, webbing between arms. Scale bars = $4 \mathrm{~cm}$.

(except possibly the very small ones at the tips of the arms) appeared capable of luminescence. No other portion of the body was observed to emit light.

\section{Morphology of photophores}

Each photophore is a raised papilla-like structure partially embedded in the connective tissue of the arm. The photophores are composed of three layers of cells: an outer epithelium modified to form a collar, infundibulum, and acetabulum; a capsule-like mass of muscle and neural tissue beneath the epithelium; and a thin layer separating the capsule from the dermis of the arm (Figs. 3, 4, 5). The collar epithelium is continuous with the epidermis and is folded inward, forming a rim around the central portion of the photophore (Figs. 3B, C; 4A). In both formalin- and glutaraldehyde-preserved specimens, the photophores appear to be either everted above (Fig. 3B) or retracted below (Fig. $3 \mathrm{C})$ the outer edge of the collar.

\section{Outer epithelium}

The outer and inner folds of the collar epithelium are morphologically distinct and are different from the epidermis covering the arm (Figs. 5, 6). The epidermis of the arm is squamous to cuboidal in character and consists of epithelial cells possessing scattered apical microvilli (Fig. 6A). The outer edge of the collar is composed of columnar cells with apical microvilli, numerous electron-lucent and electron-dense vesicles, and large, apically placed, elongated nuclei (Fig. 6B). Like the epidermis, this region of the collar is not covered by a cuticle.

The inner edge of the collar is similar in cellular morphology to the outer collar epithelium except that the microvilli are more densely arranged and are covered by a cuticle (Figs. 6C, D). In this region, the cuticle is composed of at least three layers: an outer lamina $0.3 \mu \mathrm{m}$ thick with irregular projections; a second electron-dense lamina, also $0.3 \mu \mathrm{m}$ thick; and an inner layer approximately $1 \mu \mathrm{m}$ thick consisting of amorphous material.

The epithelium and the overlying cuticle of the inner edge of the collar continue as the epithelium of a flat recessed region of the photophore corresponding to the infundibulum of typical octopod suckers (Figs. 3B; 4A; 5A, B). The outer edge of the infundibulum is ringed by hook-shaped denticles (Fig. 4B-D), which are elaborations of the cuticle (Fig. 6C, D). In addition to the presence of denticles, the cuticle covering the infundibular epithelium differs from that described for the inner part of the collar in that the outer layer contains more irregular projections and the innermost lamina is greatly expanded. The cuticle in this region is apparently secreted by the infundibulum and, as supported by Figure $6 \mathrm{C}$ and $\mathrm{D}$, is periodically molted and replaced by a new, pre-formed cuticle. Subcuticular spaces were observed in association with what appear to be newly forming denticles.

Three cell types_-gland cells, columnar epithelial cells, and multiciliated cells-were observed in the infundibular epithelium. Gland cells with narrow apical necks and a reduced number of apical microvilli are situated between columnar epithelial cells, which are characterized by a brush border of branched microvilli, rounded apical nuclei, apical endocytic vesicles, and mitochondria (Fig. 7A). Both columnar cells and gland cells have a fine granular cytoplasm replete with Golgi bodies and electron-dense and electronlucent vesicles of varying sizes (Fig. 7B, C). Electron-dense granules, not bounded by a membrane, were observed between microvilli. These presumably originate from the infundibular cells and are incorporated into the cuticle (Fig. 7C). Multiciliated columnar cells were infrequently observed as part of the infundibulum. Cilia were not found in epidermal or collar cells. The cilia of the infundibular cells have two nearly parallel striated rootlets and appear to have reduced axonemes that do not project above the level of the 

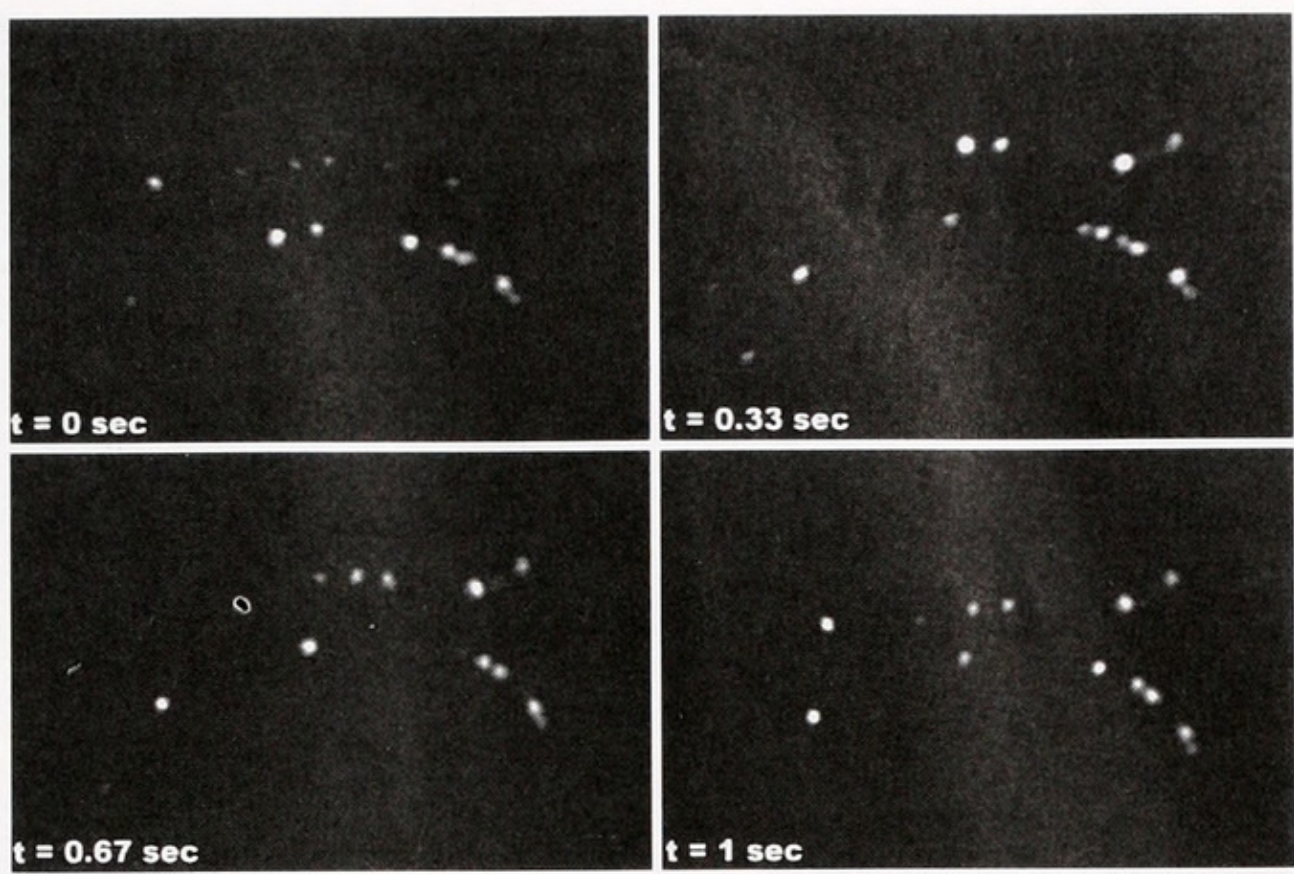

Figure 2. Digitized frames from a video sequence of light emission (white spots) from photophores/suckers taken from video of an animal filmed in the dark using an intensified video camera (Intevac's NiteMate 1305/1306 CCTV Intensifier coupled to a Panasonic CCD). Two arms are shown. For scale, their closest approach is approximately $1 \mathrm{~cm}$.

microvilli (Fig. 7C). All three cell types are interconnected by apical adherens and subapical septate junctions (Fig. 7D).

At the center of the light organ, the infundibular epithelium invaginates to form the acetabulum, which is seen externally as an opening, or pore (Figs. 3B, 4A). This central opening continues internally as a blind canal (Fig. $5 \mathrm{C})$. The acetabular cells differ from those of the infundibulum primarily in the basal position of the nuclei, the highly interdigitated lateral membranes, and the diminution of the outer two layers of the cuticle (Figs. 5C; 8A, B).

The infundibulum and the acetabulum rest on a basal lamina beneath which is located an expanded layer of connective tissue with a maximum thickness of $1.5 \mu \mathrm{m}$ (Figs. 5C; 8C, D). Fibers, presumably collagen, although confirmation of this is not provided by the data, are arranged in alternating directions in multiple layers, giving the tissue a herringbone appearance. Occasional breaks, traversed by nerve axons, were observed in this otherwise continuous connective tissue sheath.

\section{Muscle and neural tissue}

Beneath the connective tissue underlying the epithelium of the infundibulum and acetabulum is a mass of tissue consisting of muscle and neural cells; this surrounds and encapsulates the outer epithelium (Figs. 5; 8A, E; 9). The myofilaments, which include thick filaments ( 25 and $50 \mathrm{~nm}$ in diameter) and thin filaments consistent with the size of myosin and actin, are oriented in three planes-circular, radial, and longitudinal with respect to the axis of the photophore. Although all sections were taken in the longitudinal plane of the photophore, the precise plane of each section for these transmission electron micrographs was not known. Thus, the differentiation of the fibers seen in Figure 8C (shown in cross-section) and Figure 9A (horizontal fibers shown in longitudinal section) as circular or radial cannot be determined.

Intermingled with the muscle cells are nerve cells characterized by electron-dense granules $0.1 \mu \mathrm{m}$ in diameter. Nerve axons are located throughout the capsule and especially in the basal region closest to the dermis (Fig 9B). Although a direct connection was not documented, fluorescent images of the photophores indicate that axons originating from the large branchial nerve traverse the dermis and connect to the photophore.

The innermost layer of the photophores is an epithelium that separates the muscular capsule from the dermis of the $\mathrm{arm}$. The cells of this layer have interdigitated lateral membranes and a cytoplasm that appears more granular than that of the outer epithelium. This layer is associated with extrinsic (to the photophore) muscle cells (Fig. 9A) and a blood vessel located in the dermis (Fig 9B).

\section{In situ behavior}

Animal 1 (from Cape Hatteras) was first seen in a bell posture with its fins sculling (Fig. 10A). It then moved away from the submersible, using a slow medusoid locomotion. After one contraction/expansion cycle, the animal closed its 

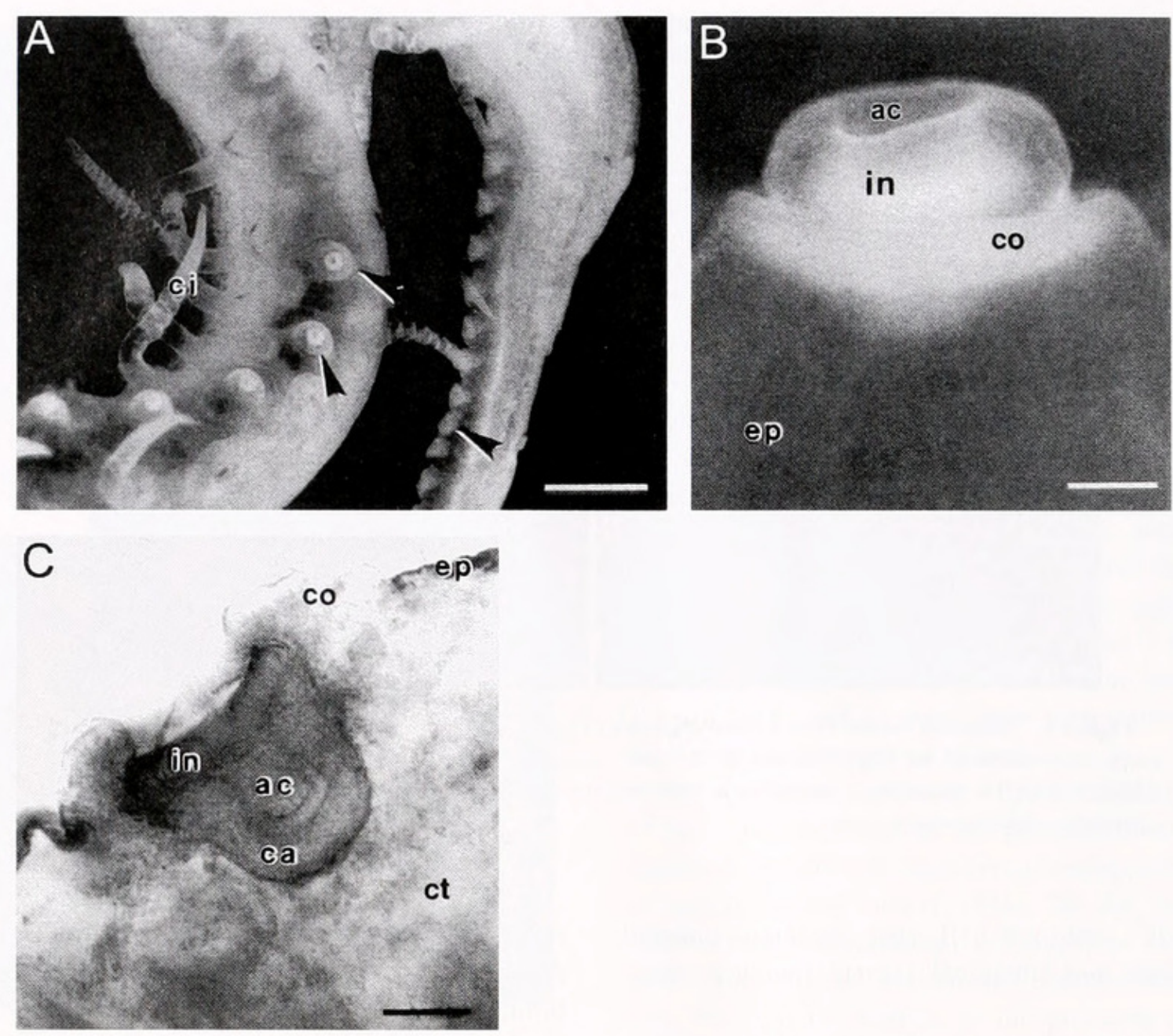

Figure 3. (A) Photograph of part of an arm of Stauroteuthis syrtensis with the webbing removed. Photophores (arrowheads) are arranged in a single row along the length of the arm and are unequally spaced with decreasing distance between light organs at the proximal tip of the arm. The positions of the photophores alternate with the positions of the cirri (ci). Scale bar $=0.5 \mathrm{~cm}$. (B) Light micrograph of a fluorescent image of a single formalin-fixed photophore in the extended position. Like octopus suckers, the photophore is elevated above the epidermis (ep), is surrounded by a collar of epidermal cells (co), and consists of an infundibulum (in) and central acetabular canal (ac). (C) Light micrograph of a retracted photophore that has been bisected longitudinally. Internally, a capsule-like mass of tissue (ca) underlies the epithelium of the infundibulum and acetabulum. ct, dermal connective tissue of the arm. Scale bar for B and C $=0.1 \mathrm{~mm}$.

web and assumed a highly distended balloon posture with motionless fins (Fig. 10B). After several minutes in this posture, the arms opened to a bell posture, and then closed to a considerably smaller balloon posture (Fig. 10C) referred to as the "pumpkin posture" by Vecchione (pers. comm.). After $2 \mathrm{~min}$, the fins began sculling and the animal made one more medusoid contraction and then again closed its web to the pumpkin posture with fins sculling. After a minute, the animal made about seven more medusoid contractions and then closed to the pumpkin posture with fins sculling and head down.

Animal 2 (from Oceanographer Canyon) was first seen with its arms spread in the horizontal plane with the mouth oriented upwards (Fig. 10D). It underwent one medusoid contraction and then inflated to a highly distended balloon posture with fins motionless and cirri extended and pressed against the primary web. After several minutes, the fins began sculling and the animal simultaneously twisted its body and opened its arms (Fig. 10E).

Animal 3 (from Oceanographer Canyon) was first seen in a bell posture. Then, using slow medusoid locomotion, moved away from the submersible. During the escape, its fin sculled continuously and sometimes vigorously. During expansion of the primary web, the cirri could be seen and were extended perpendicular to the arms and pressed against the primary web.

\section{Discussion}

Morphology of photophores and homology with octopus suckers

Although the anatomical position and morphology of the light organs of $S$. syrtensis indicate their homology with octopod suckers, other aspects of their structure are consis- 

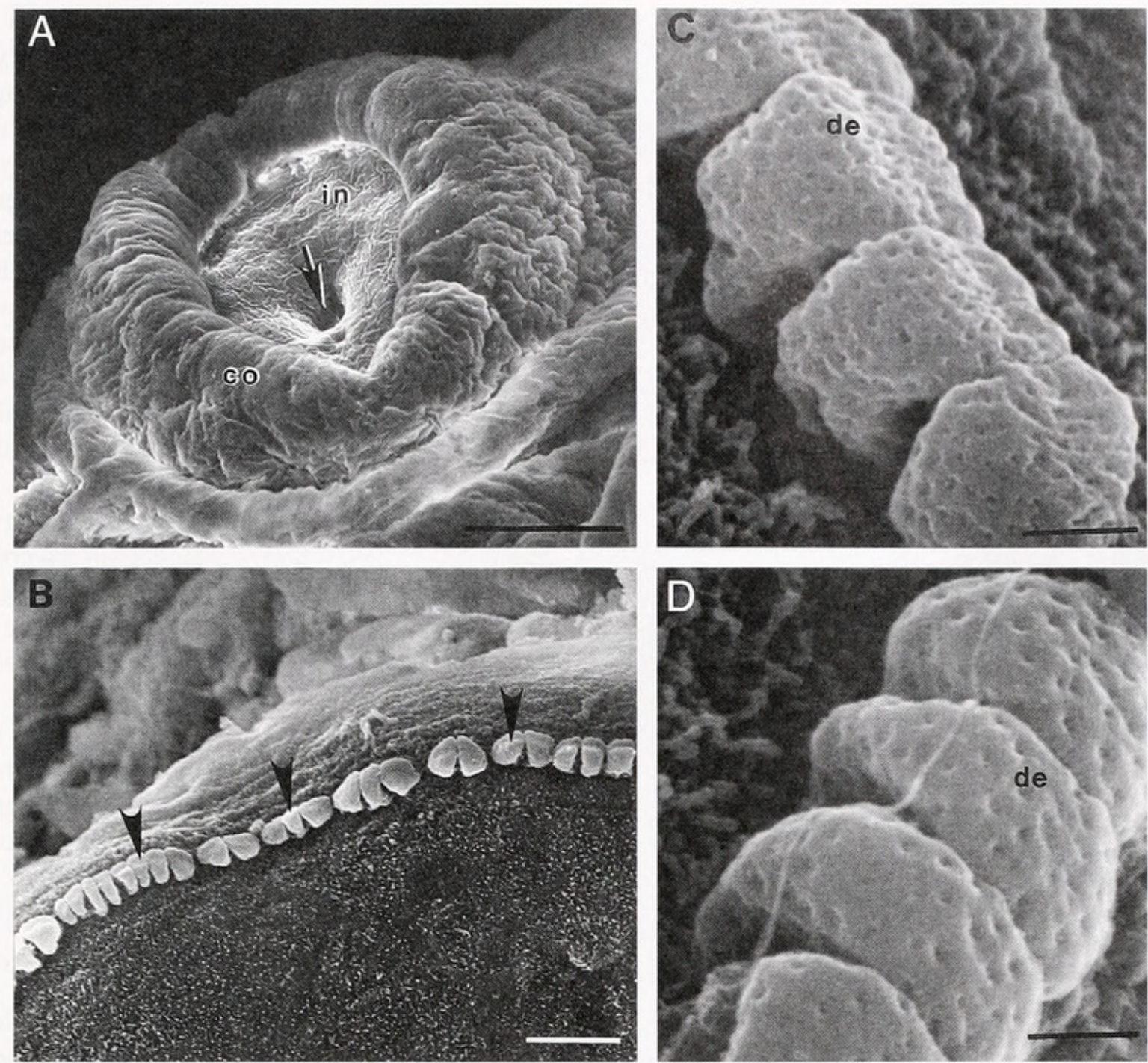

Figure 4. Scanning electron micrographs of photophores. (A) Externally, each photophore has three main recognizable parts: outer wall or collar (co), infundibulum (in), and acetabulum (arrow indicates the opening to the acetabular canal). Scale bar $=100 \mu \mathrm{m}$. (B) The junction between the infundibulum and the infolded collar is ringed by a row of denticles (arrowheads). Scale bar $=10 \mu \mathrm{m}$. (C-D) These hook-like denticles (de), which are atypical of octopod suckers, appear to be elaborations of the cuticle covering the infundibulum and acetabulum. Scale bars for C and D = $1 \mu \mathrm{m}$. A and B adapted from Johnsen et al. (1999), with permission from Nature, copyright 1999 Macmillan Magazines Ltd.

tent with those reported for simple photophores in other cephalopods (Young and Arnold, 1982; Herring et al., 1987, 1994). Definitive structural characteristics of octopod suckers are given by Kier and Smith (1990) and Budelmann et al. (1997). Like the suckers of other cirrate octopods, the photophores of $S$. syrtensis are arranged in a single row along the oral surface of the arm with the largest, most developed organs located at the base of the arm, nearest the mouth. Suckers and these photophores both consist of three layers of tissue: an outer epithelium, an intrinsic muscular layer, and an extrinsic layer associated with muscle cells. The outer epithelium is covered by a cuticle that, as in suckers, appears to be periodically molted. Moreover, the epidermis associated with the photophore is modified to form the columnar epithelial cells of the recessed infundibulum and the invaginated acetabulum. The arrangement of myofilaments in the muscular capsule are consistent with the three-dimensional array of contractile fibers typical of suckers. Although this may be an artifact of fixation, the morphology and the arrangement of myofilaments would allow for the retraction and extension, as well as a change in the diameter, of the photophore and may be important in regulating the intensity of the emitted light.

Although denticles are not common in octopod suckers (Nixon and Dilly, 1977; Budelmann et al., 1997), hooks and denticles of various sizes are found in decapod cephalopods. The functional significance, especially with the apparent loss of an adhesive function for the suckers, of the denticles on the photophores of S. syrtensis is unknown. They may, however, be vestigial structures indicating an evolutionary connection to the decapods.

Although definitive morphological characteristics are 


\section{A}
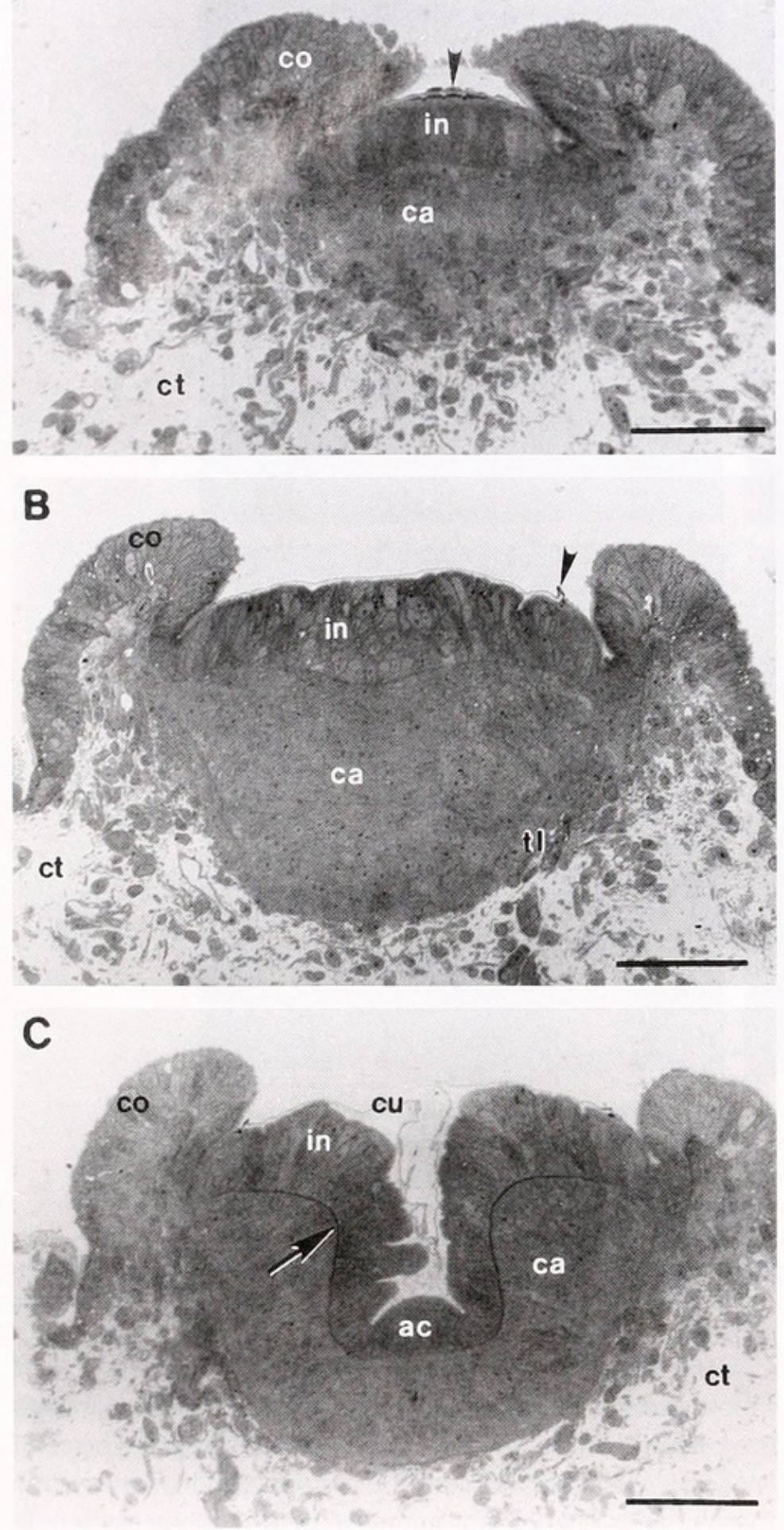

Figure 5. Light micrographs of a series of semithin sections from the outer edge of the infundibulum (A), through the middle region of the infundibulum (B), to the center of the acetabular canal (C). Each photophore consists of an outer epithelium that is recessed below the level of a supporting epidermal collar (co). This epithelium forms the infundibulum (in) and the acetabulum (ac) and is covered by a cuticle ( $\mathrm{cu}$ ). A capsule-like mass of tissue (ca) is located below the outer epithelium and is separated from the connective tissue (ct) of the arm by a third layer of cells (tl). Arrowheads, denticles; arrow, putative reflector. Scale bars $=0.2 \mathrm{~mm}$.

lacking for photocytes in general (Herring, 1988), the epithelium of the acetabulum (and possibly of the infundibulum) is presumed to be the bioluminescent region of the photophores in S. syrtensis. Characteristics that identify photocytes in the octopod Japetella diaphana (Herring et al. 1987) and the squid Abralia trigonura (Young and Arnold, 1982) and are also found in the photophores of S. syrtensis include the presence of an amorphous, finely granular cytoplasmic ground substance containing numerous electrondense vesicles, large basal nuclei, highly interdigitated lateral plasma membranes, ciliary rootlets, and abundant Golgi bodies. To some degree, this cellular morphology is found in the cells of both the infundibulum and the acetabulum. Since these ultrastructural traits are also typical of secretory epithelia, one hypothesis is that the infundibular epithelium secretes the cuticle, and the acetabular epithelium is involved in light production.

Reflectors in cephalopod photophores are typically composed of collagen fibers arranged in layers beneath the photocytes (Young and Arnold, 1982; Herring et al., 1994). The layer of connective tissue separating the outer epithelium and the underlying capsule of muscle and nerve tissue in S. syrtensis conforms to this description. As in J. diaphana (Herring et al., 1987), the fibrous layers appear concentric with respect to the axes of the photophore and alternate in orientation. In a longitudinal tangential section, this arrangement would produce the herringbone effect seen in the putative reflector of $S$. syrtensis.

\section{The functional significance of bioluminescence}

The replacement of adhesive suckers with photophores might have occurred during colonization of the pelagic deep sea from the shallow-water benthos. However, the significance of this transition and the function of the light emissions are, at present, unknown. One function of light emission common to almost all bioluminescent animals is defense (reviewed in Widder, 1999). The vast majority of bioluminescent animals emit light when disturbed, perhaps to startle predators or to attract larger animals that may prey upon the predator. Feeding experiments have shown that feeding rates of predators are diminished in the presence of bioluminescence (see Widder, 1999, for further details). Since $S$. syrtensis emitted light in response to physical disturbance, it is likely that defense is at least one function of its light emission.

The functions of bioluminescence in deep-sea animals are difficult to determine because these animals are seldom observed in their own environment, and then only under bright lights that both mask natural light emissions and affect behavior. Therefore, the following discussion is based on circumstantial rather than direct evidence and is necessarily speculative. On the basis of the anatomical distribution of the photophores, the optical characteristics of the emitted light, and the behavior of the animal, we propose two more functions for bioluminescnce in S. syrtensis: sexual signaling and light luring. Visual communication is 

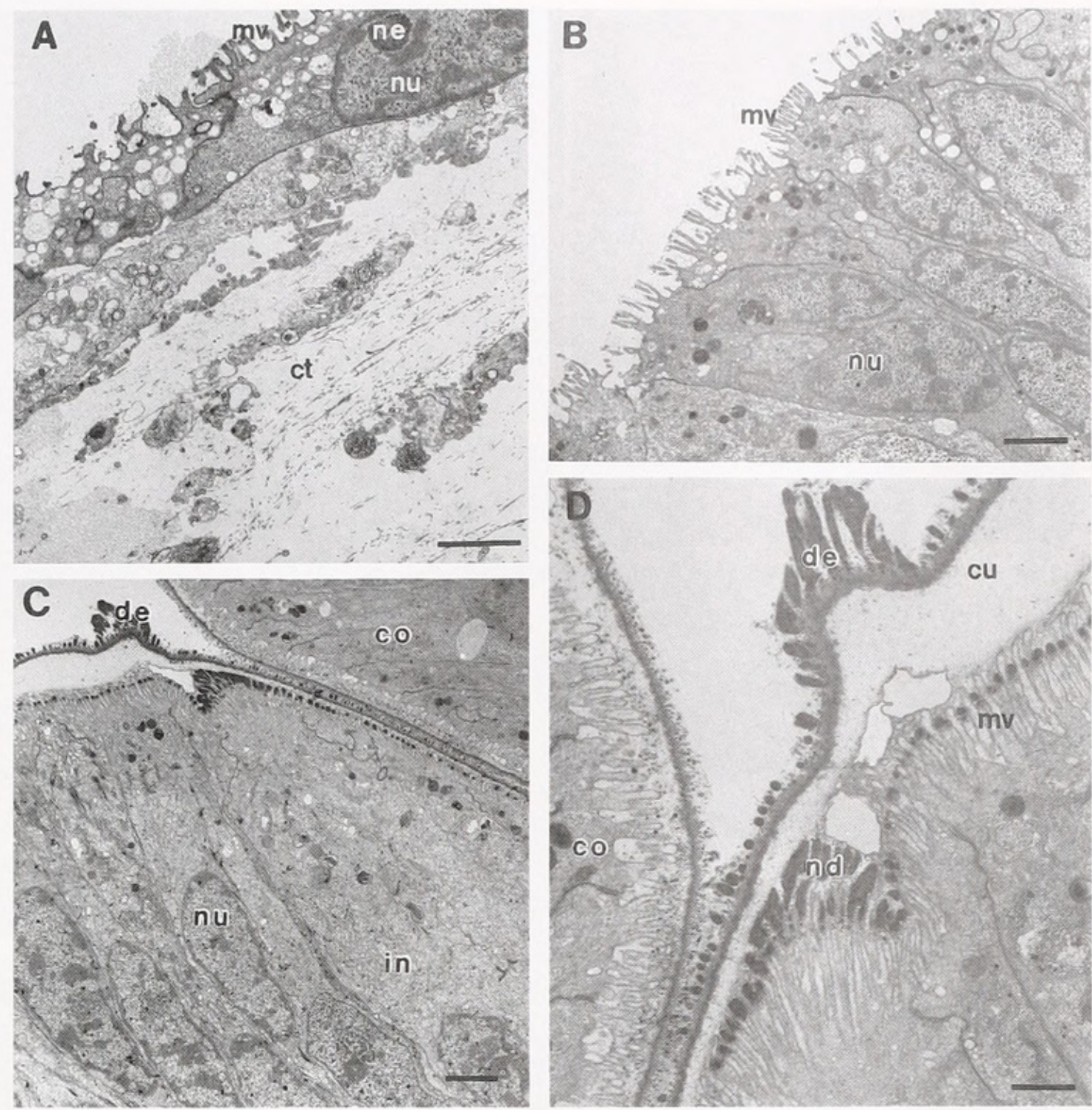

Figure 6. Transmission electron micrographs of tangential longitudinal sections through the epidermis (A). outer rim of the collar (B), and the inner rim of the collar and outer edge of the infundibulum (D and C). These, as do all TEM images, represent sections taken in the longitudinal axis of the photophore. The epidermis is composed of flat cells with scattered apical microvilli ( $\mathrm{mv}$ ). The inner rim of the collar (co) and the infundibulum (in) are covered externally by a cuticle (cu), which at the edge of the infundibulum is modified to form denticles (de). Like the cuticle of suckers, the photophore cuticle is apparently shed and replaced by a new pre-formed cuticle (nd). ct, dermal connective tissue of the arm; ne, nucleolus; nu, nucleus. Scale bars for A, B, and C = $1 \mu \mathrm{m}$. Scale bar for $\mathrm{C}=3 \mu \mathrm{m}$.

extremely common among cephalopods (Hanlon and Messenger, 1996), and the suckers of certain shallow-water octopods have been implicated in (non-bioluminescent) sexual signaling (Packard, 1961). Indeed, sexual signaling is the proposed function of bioluminescence in the other bioluminescent genera of octopods (Robison and Young, 1981). In these animals, light organs are found only in mature breeding females. Males, immature females, and brooding females all lack this organ. In addition, Robison and Young (1981) noted that the emitted light is distinctly green (rather than the far more common blue-green) and suggested that the bioluminescence may be a private line of communication.

However, although the octoradial pattern of twinkling bioluminescence in S. syrtensis makes a highly speciesspecific signal, several factors contradict its use as a sexual signal. First, the photophores appear to be found in members of the species that, based on mantle length, are immature (Collins, unpubl. data). None of the three collected specimens were sexed by dissection. However, S. syrtensis can be externally sexed by a sexual dimorphism in suckers 9-22. In mature males, suckers 9-22 are considerably enlarged; in immature males, the enlargement is less noticeable (Collins, unpubl. data). By this method, two of the three animals were sexed as female; the sex of the third animal is unknown. All, including the animal observed from the submersible at Cape Hatteras, had the same characteristically reflective suckers. Second, the light organs' wave- 

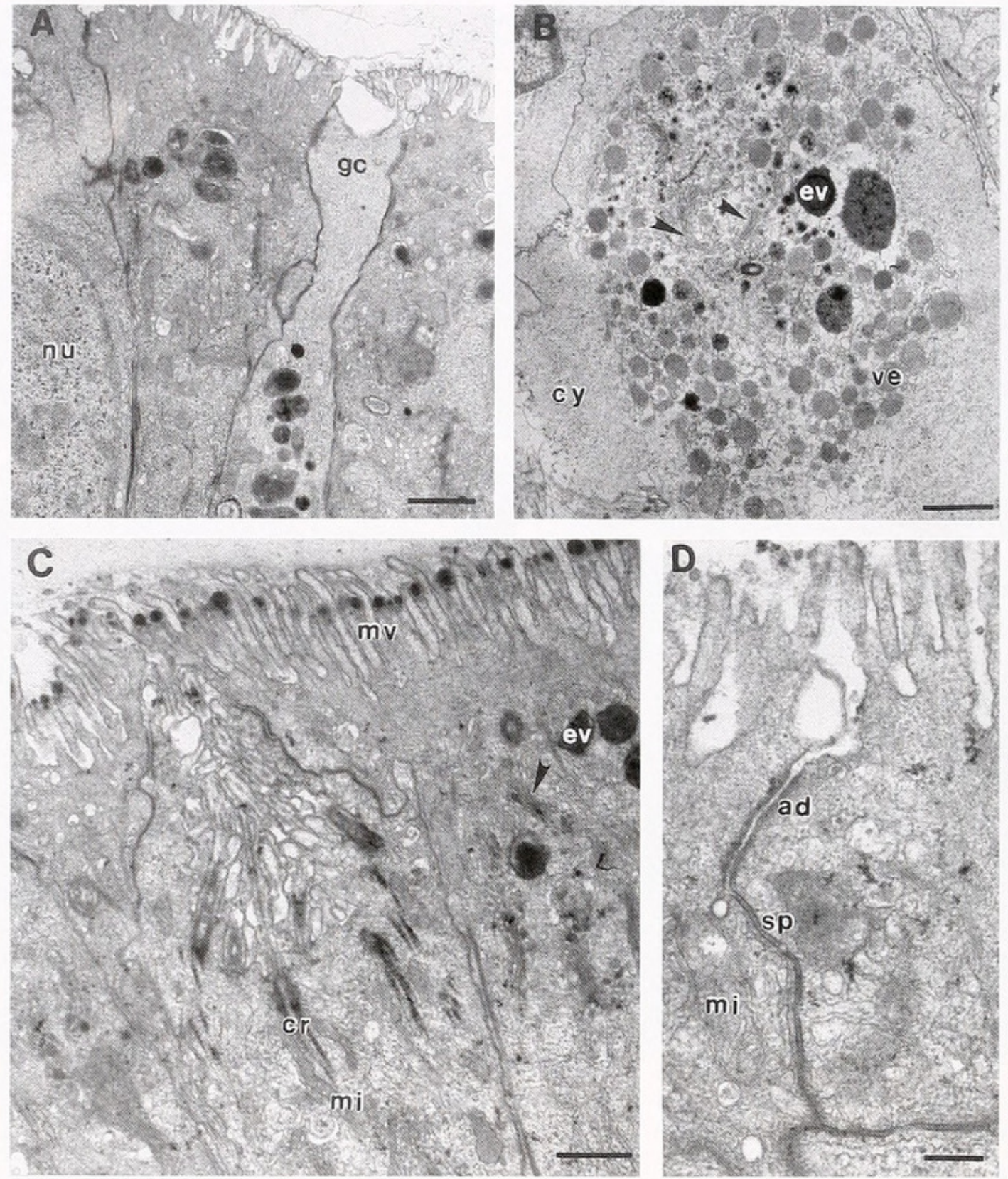

Figure 7. Transmission electron micrographs showing the details of the epithelial cells of the infundibulum. This epithelium contains gland cells ( $\mathrm{gc}$ ) and columnar epithelial cells (A) and multiciliated columnar cells (C). (A, B) Numerous electron-dense (ev) vesicles, vesicles that are less opaque (ve), and Golgi bodies (arrowheads) are found in finely granular cytoplasm (cy) of all cell types. Scale bars $=1 \mu \mathrm{m}$. (C) Both types of columnar epithelial cells are characterized by having mitochondria ( $\mathrm{mi}$ ) and a brush-border of branched microvilli ( $\mathrm{mv}$ ). A few multiciliated cells were identified by the presence of ciliary rootlets (cr) and short apical axonemes. Scale bar $=2 \mu \mathrm{m}$. (D) Infundibular cells are interconnected by apicolateral adherens (ad) and subapical septate (sp) junctions. Scale bar $=0.5 \mu \mathrm{m}$. nu, nucleus.

length of peak emission closely approximates the wavelength of maximum light transmission in the ocean $(475$ $\mathrm{nm}$ ) and the usual peak wavelengths of bioluminescence and visual sensitivity in deep-sea animals (Jerlov, 1976; Herring, 1983; Widder et al., 1983; Frank and Case, 1988; Partridge et al., 1992; Kirk, 1983). Therefore, though the bioluminescent signal would be visible at long distances to other members of $S$. syrtensis, it would also be visible at long distances to potential predators. In addition, since the octoradial pattern would be distorted by light scattering after a short distance underwater (Mertens, 1970), it would be difficult to distinguish from the many other bioluminescent signals of similar wavelength.

A more attractive hypothesis is that bioluminescence in $S$. syrtensis functions to lure potential prey. Voss (1967) has previously suggested that the photophores in some cephalopods function as light lures, and this function in $S$. syrtensis is supported by the following line of evidence. The cirrate genera Stauroteuthis, Cirroteuthis, and Cirrothauma feed on small planktonic crustaceans, and other researchers 

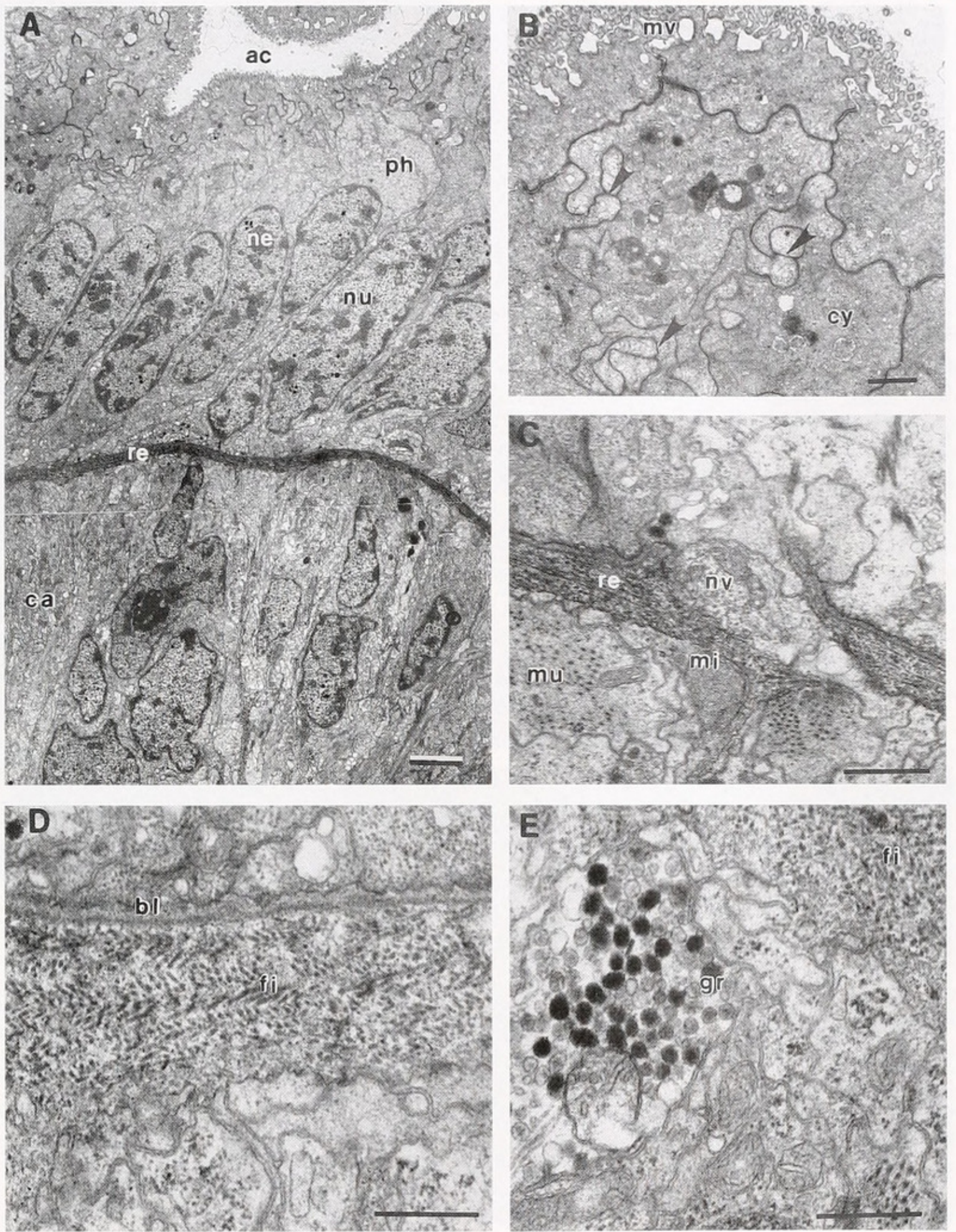

Figure 8. Transmission electron micrographs of the acetabular epithelium (A-C), the putative reflector (D), and distally positioned cells in the capsule of tissue beneath the outer epithelium (E). (A) A montage showing the presumptive photocytic epithelium (ph), reflector (re), and the underlying capsule (ca) of muscle and nerve cells. Scale bar $=3 \mu \mathrm{m}$. (B) Like photocytes of other cephalopods, the cells of the acetabulum have highly digitized lateral membranes (arrowheads) and a finely granular cytoplasm (cy). Scale bar $=0.5 \mu \mathrm{m}$. (C, D) A layer of connective tissue separates the acetabular epithelium from the underlying muscle (mu) and nerve cells. Breaks in the connective tissue layer are bridged by neurons (nv). Fibers (fi) in the connective tissue are arranged in layers with alternating orientation, giving the tissue a herringbone appearance. Scale bars $=0.5 \mu \mathrm{m}$. (E) Presumptive neurons with electron-dense granules (gr) are found throughout the capsule. Scale bar $=0.5 \mu \mathrm{m}$.

have suggested that these are trapped within a mucous web produced by buccal secretory glands and handled by the elongated cirri (Vecchione, 1987; Vecchione and Young,
1997). Since all three genera appear to have nonfunctional suckers (Aldred et al., 1983; Voss and Pearcy, 1990), this method of feeding seems likely. In all three genera, the 

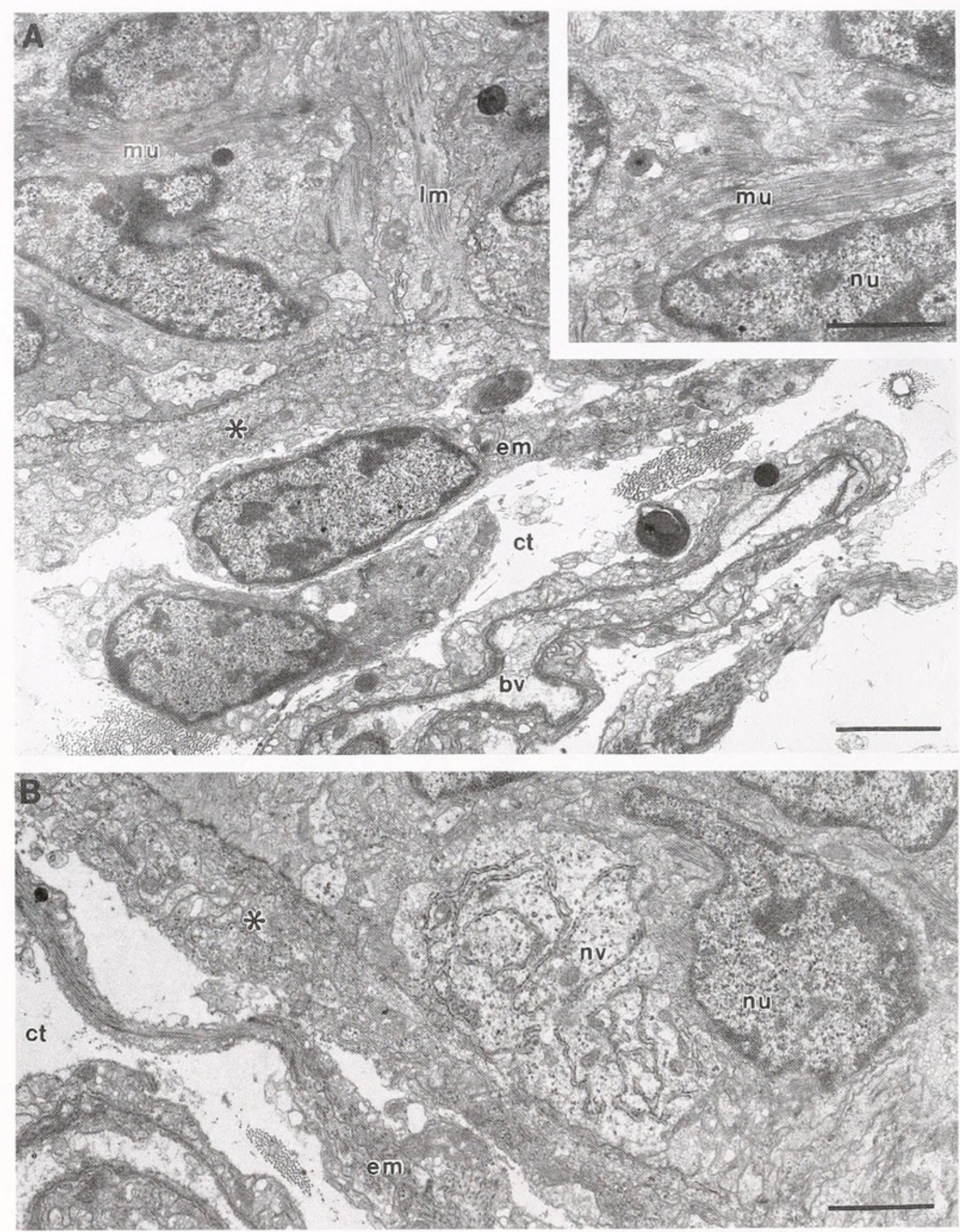

Figure 9. (A, B) Transmission electron micrographs of the medial region of the capsule and of the third innermost cell layer of the photophore. The capsule, like the intrinsic musculature of suckers, consists, in part, of cells with myofilaments arranged in three planes (also see inset). Longitudinal ( $\mathrm{m}$ ) and horizontal fibers (mu) alternate throughout the capsule. Inset shows thick and thin filaments consistent with the size and appearance of myosin and actin. Neural axons (nv) are intermingled with muscle cells. The capsule is separated from the connective tissue of the arm (ct) by a third layer of cells $\left(^{*}\right)$, which is associated with extrinsic muscle cells (em). bv, lumen of a blood vessel; nu, nucleus. Scale bars $=1 \mu \mathrm{m}$.

shape of the primary web precludes any flow-through feeding current. Therefore, the prey cannot be filtered from the water column, but must somehow be attracted to the mucous web. Since many deep-sea crustaceans have well-developed, sensitive eyes and are attracted to light sources (Morin et al., 1975), the photophores of S. syrtensis may provide the lure.

With the exception of the twisting behavior following ballooning (observed only once), the in situ behaviors of the three specimens of $S$. syrtensis reported here are similar to 

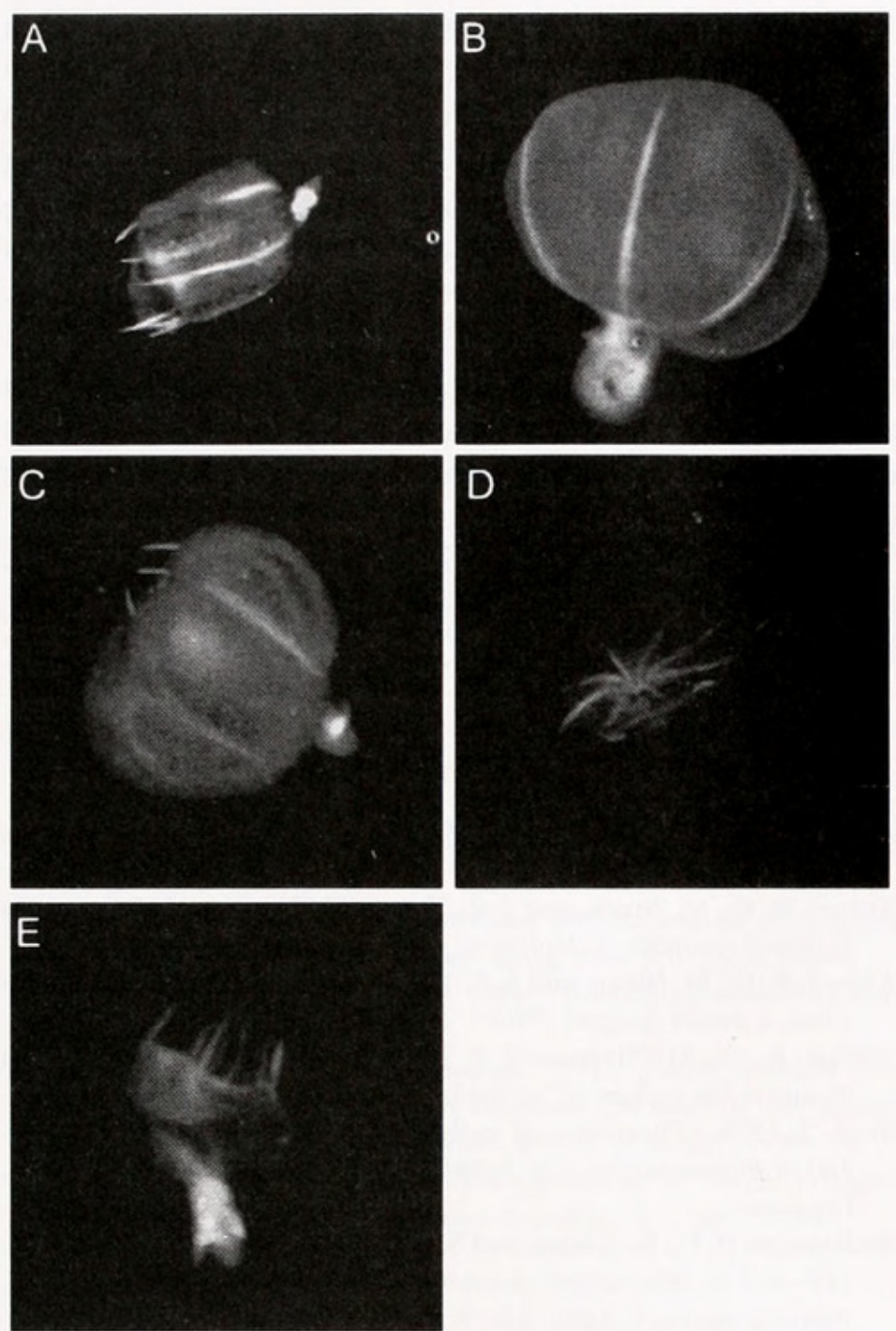

Figure 10. Digitized frames of in situ video of Stauroteuthis syrtensis. (A) bell posture; (B) distended balloon posture; (C) pumpkin posture (distinguished from the balloon posture by the fact the web is not fully inflated); (D) inverted umbrella posture; (E) animal twisting and opening its arms after ballooning. The highlights on the mantle in $\mathrm{A}, \mathrm{C}$, and $\mathrm{E}$ are reflections from the submersible lights.

those described from videos of two other specimens observed by Vecchione and Young (1997). When first approached, S. syrtensis is generally found with its arms spread in an umbrella or bell posture, with the mouth oriented either upwards or downwards (Roper and Brundage, 1972; Vecchione and Young, 1997; Villeneuva et al., 1997). Since the animal almost certainly detects the relatively large and well-lit submersible well before itself being captured on video, it is difficult to know whether this is the natural posture or a defensive reaction. Given the assumption that the animals are in an undisturbed, non-withdrawal state when first filmed, their posture and the location of their photophores are consistent with the use of bioluminescence as a lure. As mentioned above, the wavelength of peak emission approximates the wavelength of maximum light transmission. This suggests that the emission spectrum of the photophores has been selected for maximum visibility.
Finally, because the intensity of upwelling light is only a small percentage of that of downwelling light (Denton, 1990), animals bioluminescing in the mouth-up posture would be highly visible to potential prey in shallower depths. Collectively, these observations give credence to the idea that $S$. syrtensis uses photophores to attract prey.

\section{Existence and evolution of photophores in octopods}

Aside from the present study, the only other conclusive evidence of bioluminescence in octopods is restricted to the breeding females of the family Bolitaenidae (Herring, 1988). However, the existence of light organs within suckers (at the base of the peduncle) has been suggested in the cirrate octopod C. murrayi (Chun, 1910, 1913). As in the photophores of S. syrtensis, these organs have a bright white appearance due to reflection from a connective tissue layer and are found in suckers that have many reduced traits compared to typical octopod suckers (Aldred et al., 1983). Unlike the photophores of $S$. syrtensis, the postulated light organs of $C$. murrayi are not found within the sucker itself. In addition, the connective tissue layer is situated such that the produced light would be reflected into the tissue of the arm. After a complex subsequent study (Aldred et al., 1978, 1982, 1983), Aldred et al. (1984) tentatively interpreted the organs as unusual nerve ganglia (see also Vecchione, 1987).

Because photophores and photocytes have a bewildering variety of morphologies (Buck, 1978; Herring, 1988), conclusive determination of the presence or absence of light organs (which often emit only dim light) requires observation of a healthy specimen in near-total darkness by a thoroughly dark-adapted observer (i.e., in near-total darkness for a minimum of $10 \mathrm{~min}$ ) (Widder et al., 1983). Owing to the bright lights of submersibles and remotely operated vehicles, bioluminescence is seldom observed in situ. In addition, since most bioluminescent animals produce light when disturbed, deep-sea cephalopods collected in nets generally have exhausted their light production by the time they reach the surface. Finally, observations of spontaneous luminescence are rare; most bioluminescent animals must be physically stimulated (often for a considerable period of time) before light is observed (Widder et al., 1983).

The evolutionary history of photophores in any animal group is extremely difficult to determine because bioluminescence has no fossil record (Buck, 1978). The evolution of bioluminescence in the coleoid cephalopods is particularly intriguing because of the extraordinary diversity and complexity of photophores in deep-sea decapods and vampyromorphs and their apparent rarity and simplicity in deep-sea octopods (Herring, 1988). However, bioluminescence in the deep-sea octopods may not be as rare as previously assumed. For the reasons given in the previous paragraph, bioluminescence may be under-reported in the deep-sea octopods. Cirrothauma murrayi and Cirroteuthis 
are found at abyssal depths (except in polar regions, where they can be found at the surface) (Voss, 1988), making capture of healthy specimens extremely difficult. Opistoteuthis is found at shallower depths and has been maintained in aquaria (Pereyra, 1965), but it is not known whether it was observed under the specialized conditions necessary to detect bioluminescence. However, given that Opistoteuthis feeds on a variety of benthic prey that it apparently captures using functional suckers (Villaneuva and Guerra, 1991), if it is bioluminescent, its photophores are probably in a different site.

Octopod bioluminescence may exist only in S. syrtensis and the bolitaenids. A cladistic analysis of the Octopoda involving 66 morphological characters places the cirrates basal to the incirrates and the bolitaenids basal among the incirrates (Voight, 1997). This analysis also supports the monophyly of the bolitaenids and the two clades (Cirroteuthidae and Stauroteuthidae) composing the genera Stauroteuthis, Cirrothauma, and Cirroteuthis. The homology of the photophores in S. syrtensis and the bolitaenids is unlikely. The photophores of $S$. syrtensis appear to exhibit the rare trait of muscle derivation. The only other example of muscle-derived light organs has been found in the scopelarchid fish Benthalbella infans (Johnston and Herring, 1985). Although the luminous circumoral ring in the bolitaenid Japetella diaphana is initially a muscular band, the great increase in the size of the ring in adult females apparently requires de novo synthesis of luminous tissue (Herring et al., 1987). In addition, the light organs differ in almost all other anatomical and morphological characteristics. Finally, only mature female bolitaenids have light organs, which appear to have a sexual function, whereas the light organs of $S$. syrtensis are found in immature animals and may be involved in feeding. Multiple independent evolutions of photophores are common in decapods, at least at taxonomic ranks of subfamily or higher (Young and Bennett, 1988; Herring et al., 1992, 1994). Therefore, despite the close evolutionary relationship between the cirrates and the bolitaenids, photophores in these two groups seem to have evolved independently. However, the monophyly of Stauroteuthis, Cirroteuthis, and Cirrothauma and the fact that they all have suckers with reduced traits suggest the possibility of light production by modified suckers in the latter two genera.

\section{Acknowledgments}

We thank the captain and crew of the R.V. Edwin Link and the Johnson-Sea-Link pilots, Phil Santos and Scott Olsen, for assistance with all aspects of animal collection. We also thank Dr. Tamara Frank for a critical reading of the manuscript, Dr. Michael Vecchione for aid with identifying the specimens, Dr. Janet Voight for helpful discussions on octopod evolution, and Dr. Martin Collins for use of un- published data. The authors are grateful to the Smithsonian Marine Station at Fort Pierce, Florida, for allowing the use of the photomicroscopes. Our thanks are also extended to Dr. William Jaeckle for his assistance with the scanning electron microscopy and to Julie Piriano for help with the transmission electron microscope. This work was funded by a grant from the National Oceanic and Atmospheric Administration (subgrant UCAP-95-02b, University of Connecticut, Award No. NA76RU0060) to Drs. Tamara Frank and EAW, a grant from the National Science Foundation (OCE-9313872) to Drs. Tamara Frank and EAW, and by a Harbor Branch Institution Postdoctoral Fellowship to SJ. This is Harbor Branch Contribution No. 1287 and Contribution No. 479 of the Smithsonian Station at Fort Pierce, Florida.

\section{Literature Cited}

Aldred, R. G., M. Nixon, and J. Z. Young. 1978. The blind octopus Cirrothauma. Nature 275: 547-549.

Aldred, R. G., M. Nixon, and J. Z. Young. 1982. Possible light organs in finned octopods. J. Molluscan Stud. 48: 100-101.

Aldred, R. G., M. Nixon, and J. Z. Young. 1983. Cirrothauma murrayi Chun, a finned octopod. Philos. Trans. R. Soc. Lond. B 301: 1-54.

Aldred, R. G., M. Nixon, and J. Z. Young. 1984. Ganglia not light organs in the suckers of octopods. J. Molluscan Stud. 50: 67-69.

Buck, J. 1978. Functions and evolutions of bioluminescence. Pp. 419 460 in Bioluminescence in Action, P. J. Herring, ed. Academic Press, London.

Budelmann, B. U., R. Schipp, and S. Boletzky. 1997. Cephalopoda. Pp 119-414 in Microscopic Anatomy of Invertebrates Vol. 6A, F. W Harrison and A. J. Kohn, eds. Wiley-Liss Publications, New York.

Chun, C. 1910. Die Cephalopoden. Wiss. Ergebn. dt. Thiefsee-Exped. "Valdivia" 18: 1-552

Chun, C. 1913. Cephalopoda. Pp. 1-21 in Report on the Scientific Results of the "Michael Sars" North Atlantic Deep-Sea Expedition 1910 Vol. III, Part 1, J. Murray and J. Hjort, eds. The Trustees of the Bergen Museum, Bergen

Denton, E. J. 1990. Light and vision at depths greater than 200 meters Pp. 127-148 in Light and Life in the Sea, P. J. Herring, A. K. Campbell, M. Whitfield, and L. Maddock, eds. Cambridge University Press, New York.

Frank, T. M., and J. F. Case. 1988. Visual spectral sensitivities of bioluminescent deep-sea crustaceans. Biol. Bull. 175: 261-273.

Hamner, W. M. 1990. Design developments in the planktonkreisel, a plankton aquarium for ships at sea. J. Plankton Res. 12: 397-402.

Hanlon, R. T., and J. B. Messenger. 1996. Cephalopod Behaviour Cambridge University Press, Cambridge.

Harvey, E. N. 1952. Bioluminescence. Academic Press, New York.

Herring, P. J. 1983. The spectral characteristics of luminous marine organisms. Proc. R. Soc. Lond. B 220: 183-217.

Herring, P. J. 1988. Luminescent organs. Pp. 449-489 in The Mollusca Vol. II, E. R. Trueman and M. R. Clarke, eds. Academic Press, New York.

Herring, P. J., P. N. Dilly, and C. Cope. 1987. The morphology of the bioluminescent tissue of the cephalopod Japetella diaphana (Cephalopoda: Bolitaenidae), J. Zool. Lond. 212: 245-254

Herring, P. J., P. N. Dilly, and C. Cope. 1992. Different types of photophore in the oceanic squids, Octopoteuthis and Taningia (Cephalopoda: Octopoteuthidae). J. Zool. Lond. 227: 479-491.

Herring, P. J., P. N. Dilly, and C. Cope. 1994. The bioluminescent 
organs of the deep-sea cephalopod Vampyroteuthis infernalis (Cephalopoda: Vampyromorpha). J. Zool. Lond. 233: 45-55.

Jerlov, N. G. 1976. Marine Optics. Elsevier Scientific Publishing, New York.

Johnsen, S., E. J. Balser, and E. A. Widder. 1999. Light-emitting suckers in an octopus. Nature 398: 113-114.

Johnston, I. A., and P. J. Herring. 1985. The transformation of muscle into bioluminescent tissue in the fish Benthalbella infans Zugmayer. Proc. R. Soc. Lond. B 225: 213-218.

Kier, W. M., and A. M. Smith. 1990. The morphology and mechanics of octopus suckers. Biol. Bull. 178: 126-136.

Kirk, J. T. O. 1983. Light and Photosynthesis in Aquatic Ecosystems. Cambridge University Press, Cambridge.

Mertens, L. E. 1970. In-water Photography: Theory and Practice. Wiley Interscience, New York.

Morin, J. G., A. Harrington, K. Nealson, N. Krieger, T. O. Baldwin, and J. W. Hastings. 1975. Light for all reasons: versatility in the behavioral repertoire of the flashlight fish. Science 190: 74-76.

Nixon, M., and P. N. Dilly. 1977. Sucker surfaces and prey capture. Symp. Zool. Soc. Lond. 38: 447-511.

Packard, A. 1961. Sucker display of Octopus vulgaris. Nature 190: 736-737.

Partridge, J. C., S. N. Archer, and J. Van Oostrum. 1992. Single and multiple visual pigments in deep-sea fishes. J. Mar. Biol. Assoc. U.K. 72: $113-130$.

Pereyra, W. T. 1965. New records and observations on the flapjack devilfish Opistoteuthis californiana Berry. Pac. Sci. 19: 427-441.

Robison, B. H., and R. E. Young. 1981. Bioluminescence in pelagic octopods. Pac. Sci. 35: 39-44.

Roper, C. F. E., and W. L. Brundage. 1972. Cirrate octopods with associated deep-sea organisms: new biological data based on deep benthic photographs (Cephalopoda). Smithson. Contrib. Zool. 121: 1-45.

Vecchione, M. 1987. A multispecies aggregation of cirrate octopods trawled from north of the Bahamas. Bull. Mar. Sci. 40: 78-84.
Vecchione, M., and R. E. Young. 1997. Aspects of the functional morphology of cirrate octopods: locomotion and feeding. Vie Milieu 47: $101-110$.

Villaneuva, R., and A. Guerra. 1991. Food and prey detection in two deep-sea cephalopods: Opistoteuthis agassizi and O. vossi. Bull. Mar. Sci. 49: 288-299.

Villaneuva, R., M. Segonzac, and A. Guerra. 1997. Locomotion modes of deep-sea cirrate octopods (Cephalopoda) based on observations from video recordings on the Mid-Atlantic Ridge. Mar. Biol. 129: 113-122.

Voight, J. R. 1997. Cladistic analysis of the octopods based on anatomical characters. J. Molluscan Stud. 63: 311-325.

Voss, G. L. 1967. The biology and bathymetric distribution of deep-sea cephalopods. Stud. Trop. Oceanogr. 5: 511-535.

Voss, G. L. 1988. The biogeography of the deep-sea octopoda. Malacologia 29: 295-307.

Voss, G. L., and W. G. Pearcy. 1990. Deep-water octopods (Mollusca: Cephalopoda) of the northeastern Pacific. Proc. Calif. Acad. Sci. 47: 47-94.

Widder, E. A. 1999. Bioluminescence. Pp. 555-581 in Adaptive Mechanisms in the Ecology of Vision, S. N. Archer, M. B. A. Djamgoz, E. Loew, J. C. Partridge, and S. Vallerga, eds. Kluwer Academic Publishers, Dordrecht, The Netherlands.

Widder, E. A., M. I. Latz, and J. F. Case. 1983. Marine bioluminescence spectra measured with an optical multichannel detection system. Biol. Bull. 165: 791-810

Young, R. E., and J. M. Arnold. 1982. The functional morphology of a ventral photophore from the mesopelagic squid, Abralia trigonura. Malacologia 23(1): 135-163.

Young, R. E., and T. M. Bennett. 1988. Photophore structure and evolution within the Enoploteuthidae (Cephalopoda). Pp. 241-251 in The Mollusca Vol. XII, E. R. Trueman and M. R. Clarkc, eds. Academic Press, New York. 


\section{$2 \mathrm{BHL}$ Biodiversity Heritage Library}

Johnsen, $S$ et al. 1999. "Bioluminescence in the Deep-Sea Cirrate Octopod Stauroteuthis syrtensis Verrill (Mollusca: Cephalopoda)." The Biological bulletin 197, 26-39. https://doi.org/10.2307/1542994.

View This Item Online: https://www.biodiversitylibrary.org/item/17268

DOI: https://doi.org/10.2307/1542994

Permalink: https://www.biodiversitylibrary.org/partpdf/19381

\section{Holding Institution}

MBLWHOI Library

\section{Sponsored by}

MBLWHOI Library

\section{Copyright \& Reuse}

Copyright Status: In copyright. Digitized with the permission of the rights holder.

License: http://creativecommons.org/licenses/by-nc-sa/3.0/

Rights: https://biodiversitylibrary.org/permissions

This document was created from content at the Biodiversity Heritage Library, the world's largest open access digital library for biodiversity literature and archives. Visit BHL at https://www.biodiversitylibrary.org. 